\title{
Flower Development in Walnut: Altering the Flowering Pattern by Gibberellic Acid Application
}

\author{
Amin HASSANKHAH ${ }^{1}$, Majid RAHEMI ${ }^{2}$, Mohamad Reza MOZAFARI ${ }^{3}$, \\ Kourosh VAHDATI ${ }^{1 *}$
}

\author{
${ }^{I}$ University of Tehran, College of Aburaihan, Department of Horticulture, Pakdasht, \\ Iran; hassankhah@ut.ac.ir;kvahdati@ut.ac.ir ( ${ }^{*}$ correspondingauthor) \\ ${ }^{2}$ Shiraz University, Faculty of Agriculture, Department of Horticultural Sciences, Shiraz, Iran; rahemi@shirazu.ac.ir \\ ${ }^{3}$ Agriculture and Natural Resources Research Center, Kerman, Iran;m.mozaffari@areeo.ac.ir
}

\begin{abstract}
The pattern of walnut flowering varies depending on genetic and environmental factors. To study the patterns of walnut pistillate flowers developing as a result of applying gibberellic acid $\left(\mathrm{GA}_{3}\right)$, the research was conducted as a factorial design with 2 factors (three levels of trunk diameter (10 to $12 \mathrm{~cm}, 12$ to $14 \mathrm{~cm}$ and 14 to $16 \mathrm{~cm}$ ) and four levels of $\mathrm{GA}_{3}(0,50,100$ and 200 $\mathrm{mg} / \mathrm{l})$ ) on 'Chandler' commercial cultivar. Different levels of $\mathrm{GA}_{3}$ were sprayed twice on the trees, i.e. 2 and 4 weeks after flowering. A new method was used to study the pistillate flower development based on hand-cut cross sections of bud and staining with methyl blue and carmine. Based on the results, different development stages included induction; initiation and differentiation of the pistillate flower bud were observed respectively in late May, early June, September and March. The results of $\mathrm{GA}_{3}$ application showed that $\mathrm{GA}_{3}$ treatment can alter the flowering pattern of walnut. $\mathrm{GA}_{3}$ application significantly increased the number of male flowers, total flowers, and male: female flower ratio per branch. The number of female flowers increased by increasing the tree trunk diameter. The highest number of female flowers (62.3) was observed in trees with trunk diameters between $14-16 \mathrm{~cm}$ and application of $100 \mathrm{mg} / \mathrm{l}$ of GA 3 . Linear regression analysis showed a positive and strong relation between truck diameter with total flower number as well as female flower number.
\end{abstract}

Keywords: flower induction; initiation and differentiation; Juglans regia; pistillate flowers

\section{Introduction}

Walnut trees are dichogamous and monoecious plants. A walnut male flower as catkin inflorescence can produce around two million pollen grains. In contrast, female inflorescences of most walnut species, including Persian walnut, develop as individual flowers or most commonly as two or three per inflorescence (Krueger, 2000). Walnut female flowers do not have petals, but they have a large stigma. The leaves and blossoms of the walnut tree normally appear in the spring. Usually, the development of walnut female flowers begins in May and continues until flowering in the following year (Li et al., 2011; Gao et al., 2012). Walnut is wind-pollinated and is heterodichogamous. Therefore, pollen shedding does not overlap temporally with pistillate receptivity (Golzari et al., 2016). Apparently, a single pollen grain is enough to fertilize a single ovule in walnut, while the observations from other plant species indicate that pollen loads have to be 30 to 50 times more than the number of ovules for the fruit set (Polito et al., 2003).
Pollen is required for fruit set, but the population density of pollinizers is sometimes unclear. It is commonly recommended that about $10 \%$ of the trees in each orchard be considered as pollinizers. The pollinizer trees should balance a good overlap between the staminate and the pistillate flowers of the main cultivar (Forde and Griggs, 1975). Reducing the number of pollinizer trees in the orchard could be feasible by increasing the number of catkin in walnut trees. The harvesting process can be assisted by increasing catkins in pollinizer trees.

Knowing the factors that affect flowering is essential to change the pattern of flowering in plants for particular purposes. Species exhibit differences in flower gender at the primary level (i.e. monoecy, andro- and gynomonoecy), and they are expected to show sexual plasticity in response to environmental changes (Bertin, 2007). The evolution and maintenance of these sexual systems can be explained by allowing flexibility in the allocation of resources to female and male functions in variable environments (Bertin and Kerwin, 1998; Buide et al., 2018). Sexual identity in plants is affected by environmental, hormonal and genetic factors. 
701

Environmental factors, such as high temperature and longday conditions, affect the sex of flowers in many plant species, and this can promote male flowers. On the other hand, low temperatures and short-day conditions induce the development of female flowers in cucumber plants (Li $e t$ al., 2012). The application of plant growth regulators (PGRs) have been suggested as a useful alternative to solving problems related to flowering in plants (Ghani et al., 2013).

GA is a phytohormone that promotes the normal growth and development of many plant species. It affects the sexual identity of flowers (Khryanin, 2002). GAs regulates flower initiation and development and is essential for male and female fertility. Nonetheless, GAs do not regulate the differentiation of floral organs (Griffiths et al., 2006). In recent years, significant progress has been made in understanding GA metabolism and signalling pathways, mainly through the identification and analysis of GAresponses (Ueguchi-Tanaka and Matsuoka, 2010). For example, auxin, ethylene, abscisic acid and cytokinin promote the formation of female flowers in cucumber, whereas GAs promotes the formation of male flowers (Galun et al., 1965; Iwahori et al., 1970; Galoch, 1978). The increase in a plant feminization by auxin possibly occurs through the induction of ethylene biosynthesis (Takahashi and Jaffe, 1984; Trebitsh et al., 1987). Nevertheless, GA and cytokinin in maize increase the number of female flowers (Young et al., 2004). Sladký (1972) reported that indoleacetic acid (IAA) and maleic hydrazide (MH) increased the growth of buds in branches. Generally, the effect of growth hormones is different on sex expression with respect to plant species. The objective of the present study is first to identify the time of flower induction in walnut and second to study the effect of $\mathrm{GA}_{3}$ spraying on the flowering pattern and sex expression of walnut.

\section{Materials and Methods}

\section{Plantmaterials}

The experiment was carried out using 15-year-old walnut trees cv. 'Chandler' located in a commercial orchard in Shahmirzad (Semnan province, Iran). The trees had roots in a clay-type soil that was watered by drip irrigation. A factorial test $(3 \times 4)$ was used in this experiment. Factor A was the diameter of the tree trunks, and three levels were considered (10 to $12 \mathrm{~cm}, 12$ to $14 \mathrm{~cm}$ and 14 to $16 \mathrm{~cm}$ ). Factor $\mathrm{B}$ was comprised of four levels of $\mathrm{GA}_{3}(0,50,100$ and $200 \mathrm{mg} / \mathrm{l})$.

\section{Anatomical study}

The anatomy of walnut female flower was monitored by sampling walnut buds. The sampling was performed throughout the year with 14-day intervals. Excised samples were immediately fixed in freshly prepared $10 \%$ formaldehyde, $5 \%$ acetic acid, $50 \%$ ethanol for at least $24 \mathrm{~h}$ and were dehydrated through a series of ethanol concentrations $(70 \%, 85 \%, 95 \%$ and $100 \%)$. We used handcut cross-sections for the first time in this study. Buds were cut vertically with a sharp razor. Samples were washed with distilled water and placed in 5\% sodium hypochlorite solution for 12 hours so as to clear and rinse the samples with distilled water. Following the wash in 10\% acetic acid for 2 min, cross-sections were then stained with methyl blue and carmine, respectively. Thin cut sections were observed under a microscope fitted with a digital camera.

\section{$G A_{3}$ application}

$\mathrm{GA}_{3}$ was used at four different concentrations, i.e. 0, 50, 100 and $200 \mathrm{mg} / \mathrm{l}$. Solutions were prepared by dissolving $\mathrm{GA}_{3}$ in small volumes of isopropyl alcohol and a final volume was made with demineralized water after adjusting the $\mathrm{pH}$ to 7.5-7.8. A few drops of Tween $20^{\circ}$ were added to the solution. The control group consisted of plants that were sprayed with demineralized water containing only Tween 20 . The time of spraying was in early morning hours and spraying was performed twice, i.e. 2 and 4 weeks after full bloom (time of flower induction) (Gao et al., 2012). Trees were treated seamlessly by $\mathrm{GA}_{3}$ and the leaves were sprayed thoroughly until they became fully wet (about 500 $\mathrm{ml}$ ). In total, 24 walnut trees (cv. 'Chandler') were treated in this experiment.

After treatment and in early autumn, fruits were collected and the effect of $\mathrm{GA}_{3}$ on fruit production was analysed. The numbers of male, female, ratio of male to female and total flowers were studied in the next year in spring (2016). Three branches (2 to $3 \mathrm{~cm}$ in diameter) of each tree were selected and the traits were examined. To better understand the changes in flowering patterns, the correlation between traits with different levels of $\mathrm{GA}_{3}$ and diameters of tree trunks were calculated.

\section{Statistical analysis}

The analysis of variance and Duncan's multiple range test were performed using the statistical analysis system SAS (Version 9). Also, linear regression models were performed using the SigmaPlot (Version 12.5).

\section{Results and Discussion}

\section{Female flower formation}

The formation of female flowers is influenced by external and internal signals, as vegetative buds undergo biochemical changes and as various alterations happen to the tissue along with morphological characteristics which eventually cause the transformation into flower buds. Usually, flower induction is followed by flower differentiation. The whole process of flower bud differentiation in walnut lasted one year through the two years of this study. The vegetative meristem consists of a round and flat crown that is covered by the primordia leaf and its scalloped buds. Flower bud induction was observed in late May and early June 2015. At this stage, the buds were dome-shaped and flat (Fig. 1).

Flower initiation occurred in late September. The indicator at this stage was the growth of the pedicle (Fig. 1). Female flower buds remained unchanged for a couple of months. Flower bud differentiation began on March the next year. The onset of cell division in the flower bud meristem was parallel to the formation of the bract (B) and perianth (pr) primordia (Fig. 1). Flower buds completed their development with the formation of pistils.

The anatomical structure and differentiation processes of walnut pistillate flower formation have been studied 

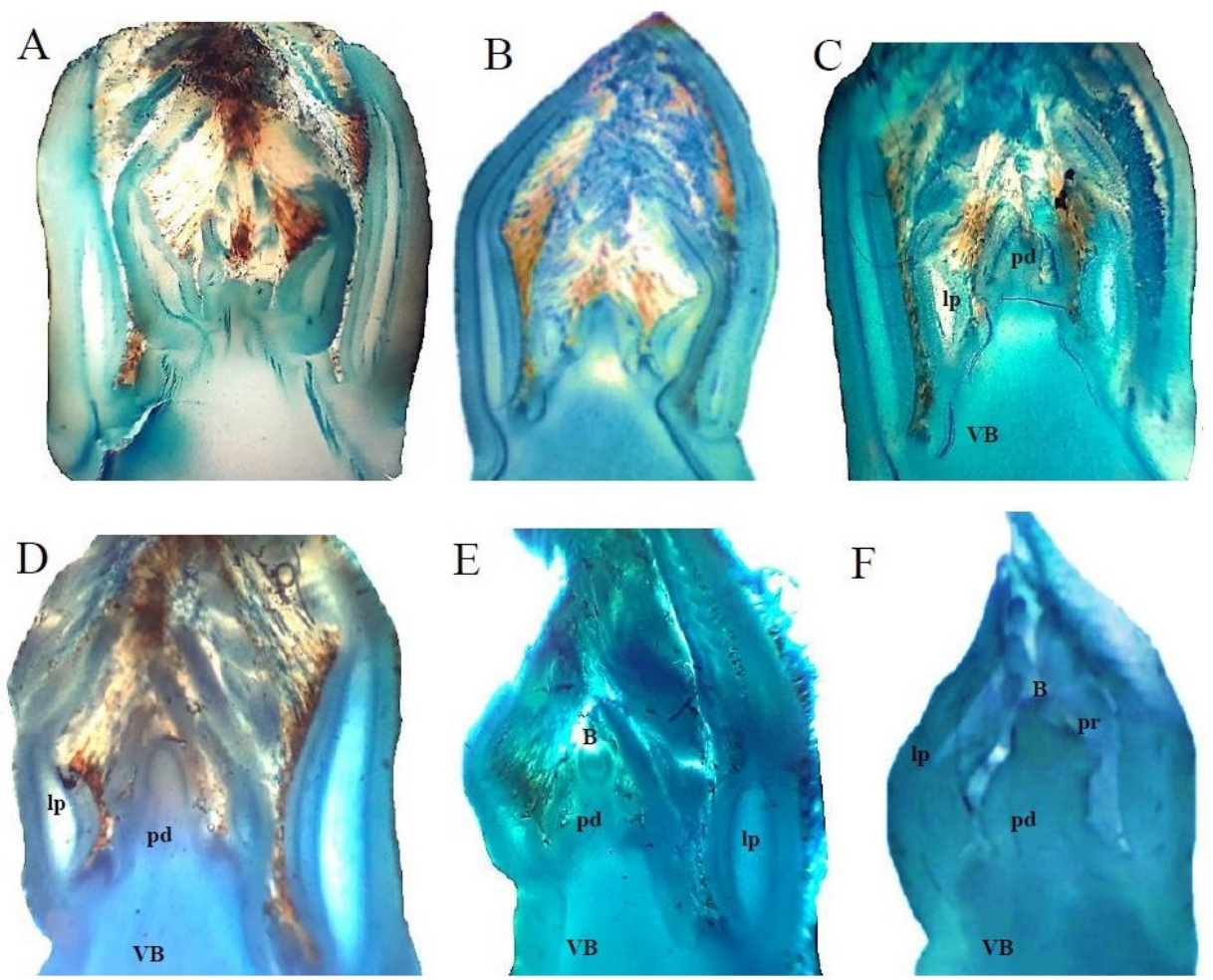

Fig. 1. Anatomy of walnut female flower bud differentiation. Floral induction periods in late May and early June. (A), floral initiation periods from September (B-D), floral differentiation periods in March to April (E and F). Pedicel (pd), bract (B), perianth (pr), vascular bundle (VB) and leaf primordial (lp)

previously. Li et al. (2011) categorized the formation processes of walnut pistillate flowers into three stages, i.e. induction, initiation and differentiation periods. In another study, five differentiation periods were recognized, and the floral induction period was divided into three stages by the anatomical structure (Gao et al., 2012). During the induction stage, the level of auxin increased in the bud (Gao et al., 2012). Also, the application of MH and IAA increased the induction of female flowers in the branches (Sladký, 1972). Our results also showed that GA increases the ratio of male to female flowers. Accordingly, the proportion of PGRs in the induction stage in a year is a decisive factor for the flowering pattern of walnut trees in the subsequent year. According to previous studies, it is possible to some degree that the flowering pattern could be controlled by knowing the timing of flower induction and its management.

\section{$G A_{3}$ application}

Based on the results, $\mathrm{GA}_{3}$ application altered the flowering pattern in walnut (cv. 'Chandler'). The effects of GAs on flowering pattern during the induction stage have been confirmed by previous studies (Makwana et al., 2010; Goldberg-Moeller et al., 2013; Makwana and Robin, 2013). The effect of GAs on flowering depends on plant species. In biennial and long-day plants, GAs promote flowering, whereas in other plants, including hermaphrodite trees, they inhibit flowering and increase biennial bearing (Wilkie $e t$ al., 2008; Goldberg-Moeller et al., 2013). The role of GAs in the flower induction of the monoecious and dioecious plants is different and more complex. Gibberellic acid in some monoecious plants increases the number of male flowers, e.g. cucumber (Iwahori et al., 1970) and in some others increases the female flowers, e.g. maize (Young et al., 2004).

The interaction between $\mathrm{GA}_{3}$ and the diameter of tree trunk was not significant (Table 1). The number of male flowers per branch significantly increased by using $\mathrm{GA}_{3} 100$ $\mathrm{mg} / \mathrm{l}$ when different diameters of the tree trunk were considered. The number of male flowers were least when 0 $\mathrm{mg} / \mathrm{l} \mathrm{GA} 3$ was applied. The number of female flowers was affected mostly by the diameter of the tree trunk. Accordingly, regardless of $\mathrm{GA}_{3}$ levels, the number of female flowers increased when considering larger diameters of tree trunk. The highest number of female flowers (62.3) was observed in tree trunks with diameters between 14-16 and $\mathrm{GA}_{3} 100 \mathrm{mg} / \mathrm{l}$. Also, the least number of female flowers (35.5) was observed in trees with diameters between 10-12 and by applying $\mathrm{GA}_{3}$ at $50 \mathrm{mg} / \mathrm{l}$. The diameter of tree trunk and the concentration of $\mathrm{GA}_{3}$ had significant effects on the total number of flowers and the male: female flower ratio. Due to the non-significant interactions between $\mathrm{GA}_{3}$ and tree trunk diameter, we examined each effect independently. The effect of $\mathrm{GA}_{3}$ on flowering is presented in Fig. 2.

In our study, $100 \mathrm{mg} / \mathrm{l}$ of GA3 significantly increased the number of male flowers $(24.2 \pm 3.1)$, total flowers $(75.3 \pm$ 7) and the ratio of male: female flowers $(0.49 \pm .06)$ per branch (Fig. 2). However, there were no significant differences in the number of male flowers by other levels of $\mathrm{GA}_{3}$ treatments. Different levels of $\mathrm{GA}_{3}$ had no significant effect on the number of female flowers. This alteration of 
703

male and female flowers caused a considerable increase in the ratio of male: female flowers. The relationship between $\mathrm{GA}_{3}$ treatment and male, female, male to female ratio and total flowers in the branch are shown in Fig. 3.

Contrary to our results, Makwana and Robin (2013) reported that $100 \mathrm{mg} / \mathrm{l} \mathrm{GA}_{3}$ treatment significantly increased the number of female flowers, total flowers and fruit yield compared to other treatments in Jatropha curcas. $\mathrm{GA}_{3}$ caused a significant decrease in the number of male inflorescences in Castanea mollissima BL. Nonetheless, there was an increase in the number of female flowers (Qiguang et al., 1985). Foliar applications of GA increased the number of female flowers and also flower development in spinach (Ćulafić and Nešković, 1980), Chinese pine (Zhao et al., 2011), maize (Irish and Nelson, 1989), Cryptomeria japonica and false cypress (Hashizume, 1973). The growth of petals and the pedicel in Cucurbita maxima L. also increased (Pimenta Lange et al., 2012). Piao Lei $e t$ al. (2012) reported that the application of GA on Corylus chinensis had no significant effect on the number of female flower buds, while it increased the ratio of male to female flowers.

Sladky et al. (1972) reported that differentiation of female flowers in the walnut is associated with a significant increase in the level of auxin-like compounds and high levels of inhibitors. Young leaves were sprayed with IAA and $\mathrm{MH}$, and it was observed that the growth of buds increased in the branches. However, the question still remains: why does GA increase male flowers in some species and female flowers in others?

Based on molecular evidence, GA regulates the development of flowers through the activation of some genes such as LFY and AP1 (Jack, 2004). Other genes, like UFO, WUS and SEP3 can act as co-factors for LFY in the activation of genes that specify the identity of the flower organ (Rijpkema et al., 2010; Murai, 2013).
According to the results, tree trunk diameter had a significant effect on the pattern of walnut flowering. The results showed that thicker trees had significantly more female flowers and total flowers, while the ratio of male to female flowers was lower. In contrast, trunk diameter did not have significant effects on the number of male flowers. The relationship between trunk diameter and walnut flowering pattern was documented after the observations (Fig. 4).

Increasing the number of flowers in the branch has a positive correlation with fruit production. Trees that exhibited lateral flowering habits developed better yield potential than terminal bearers (Amiri et al., 2010). Tree vigor correlated positively with tree height, trunk diameter, tree form, branching density, and fruit bearing type. Forde and McGranahan (1996) reported a negative correlation between tree height and yield. In contrast, Atefi (1990) found a strong positive correlation between yield, trunk diameter and height, but a negative correlation with nut weight.

Data analysis on fruit production traits in GA-treated trees showed that the treatment had no significant effect on the number of fruits, weight of each fruit, weight of total fruits and percentage of laterality (Table 2). However, in contrast to our findings, Akca et al. (2012) reported that amino ethoxy vinylglycine (AVG) and $\mathrm{GA}_{3}$ treatments (aimed at pistillate flower abortion in cv. 'Şebin') increased the production of fruit.

Different results might be due to the different periods of $\mathrm{GA}_{3}$ application treatments. Accordingly, the application of gibberellic acid during fertilization will reduce the abortion of flowers and increase production (Akca et al., 2012) because it prevents the synthesis of ethylene (Kumar et al., 2008). The use of $\mathrm{GA}_{3}$ in fertilization time is useful to prevent abortion, but we used $\mathrm{GA}_{3}$ after fertilization and during flower induction. Therefore, due to the completion of the fruit set time, the use of $\mathrm{GA}_{3}$ in flower induction time did not have a significant effect on the fruits of walnut trees.

Table 1. Effects of $\mathrm{GA}_{3}$ and diameter of tree trunk on number of male, female, ratio of male: female and total flowers in each branch of walnut trees during the flower induction

\begin{tabular}{|c|c|c|c|c|c|}
\hline \multicolumn{2}{|c|}{ Treatment } & \multirow{2}{*}{$\begin{array}{c}\text { Number of male flowers } \\
\text { per branch }\end{array}$} & \multirow{2}{*}{$\begin{array}{l}\text { Number of female } \\
\text { flowers per branch }\end{array}$} & \multirow{2}{*}{$\begin{array}{c}\text { Male: female flower } \\
\text { ratio }\end{array}$} & \multirow{2}{*}{$\begin{array}{c}\text { Total flowers per } \\
\text { branch }\end{array}$} \\
\hline Diameter of trees $(\mathrm{cm})$ & $\mathrm{GA}_{3}$ Treatments & & & & \\
\hline \multirow{5}{*}{$10-12$} & 0 & $16.8 \mathrm{cde}$ & $37.5 \mathrm{de}$ & $0.45 \mathrm{abcd}$ & $54.33 \mathrm{e}$ \\
\hline & 50 & $19.5 \mathrm{bc}$ & $35.5 \mathrm{e}$ & $0.55 \mathrm{ab}$ & $55 \mathrm{de}$ \\
\hline & 100 & $22.8 \mathrm{ab}$ & $40.8 \mathrm{cde}$ & $0.56 \mathrm{a}$ & 63.6 bcde \\
\hline & 200 & $18 \mathrm{~cd}$ & $40.8 \mathrm{cde}$ & $0.44 \mathrm{abcd}$ & $58.8 \mathrm{cde}$ \\
\hline & 0 & $13.6 \mathrm{de}$ & 44.1 bcde & $0.31 \mathrm{de}$ & $57.8 \mathrm{de}$ \\
\hline \multirow{2}{*}{$12-14$} & 50 & $19.6 \mathrm{bc}$ & 46 bcde & $0.42 \mathrm{abcd}$ & 65.6 bcde \\
\hline & 100 & $24.6 \mathrm{a}$ & $50.1 \mathrm{bc}$ & $0.50 \mathrm{abc}$ & $74.8 \mathrm{~b}$ \\
\hline \multirow{5}{*}{$14-16$} & 200 & $16.6 \mathrm{cde}$ & 45.3 bcde & 0.37 cde & 62 bcde \\
\hline & 0 & $12.8 \mathrm{e}$ & $55.5 \mathrm{a}$ & $0.23 \mathrm{e}$ & $68.3 \mathrm{bcd}$ \\
\hline & 50 & $19 \mathrm{bc}$ & $53.3 \mathrm{ab}$ & $0.35 \mathrm{cde}$ & $72.3 \mathrm{bc}$ \\
\hline & 100 & $25.3 \mathrm{a}$ & $62.3 \mathrm{a}$ & $0.40 \mathrm{bcd}$ & $87.6 \mathrm{a}$ \\
\hline & 200 & $15.5 \mathrm{cde}$ & $49.3 \mathrm{bcd}$ & $0.31 \mathrm{de}$ & 64.8 bcde \\
\hline \multicolumn{6}{|c|}{ Analysis of variance } \\
\hline \multicolumn{2}{|c|}{ Diameter of trees $(\mathrm{A})$} & Ns & ** & ** & ** \\
\hline \multicolumn{2}{|c|}{$\mathrm{GA}_{3}$ Treatments (B) } & ** & $\mathrm{Ns}$ & ** & ** \\
\hline \multicolumn{2}{|c|}{$A \times B$} & Ns & $\mathrm{Ns}$ & Ns & $\mathrm{Ns}$ \\
\hline
\end{tabular}

Mean separation within columns by Duncan's multiple range test at $5 \%$ level. 
Table 2. Effects of $\mathrm{GA}_{3}$ spray ( 2 and 4 weeks after flowering) on the walnut (cv. 'Chandler') fruits index

\begin{tabular}{|c|c|c|c|c|}
\hline $\begin{array}{l}\text { Gibberellic acid } \\
\text { Treatments }\end{array}$ & Mean of laterality on trees (\%) & Number of fruit (per tree) & Mean fruit weight (g) & Weight of total fruit $(\mathrm{g})$ \\
\hline 0 & $57.7 \pm 5.1$ & $139.6 \pm 25$ & $14.5 \pm 2.5$ & $1986.8 \pm 221$ \\
\hline 50 & $55.6 \pm 9.7$ & $128.5 \pm 28$ & $13.9 \pm 1.5$ & $1774.4 \pm 321$ \\
\hline 100 & $59.4 \pm 7.9$ & $118.3 \pm 24$ & $15.4 \pm 1.0$ & $1815.5 \pm 317$ \\
\hline 200 & $61.6 \pm 5.8$ & $177.05 \pm 32$ & $13.2 \pm 2.2$ & $2173.2 \pm 383$ \\
\hline
\end{tabular}

Duncan's multiple range test at $5 \%$ level. Mean \pm S.E.
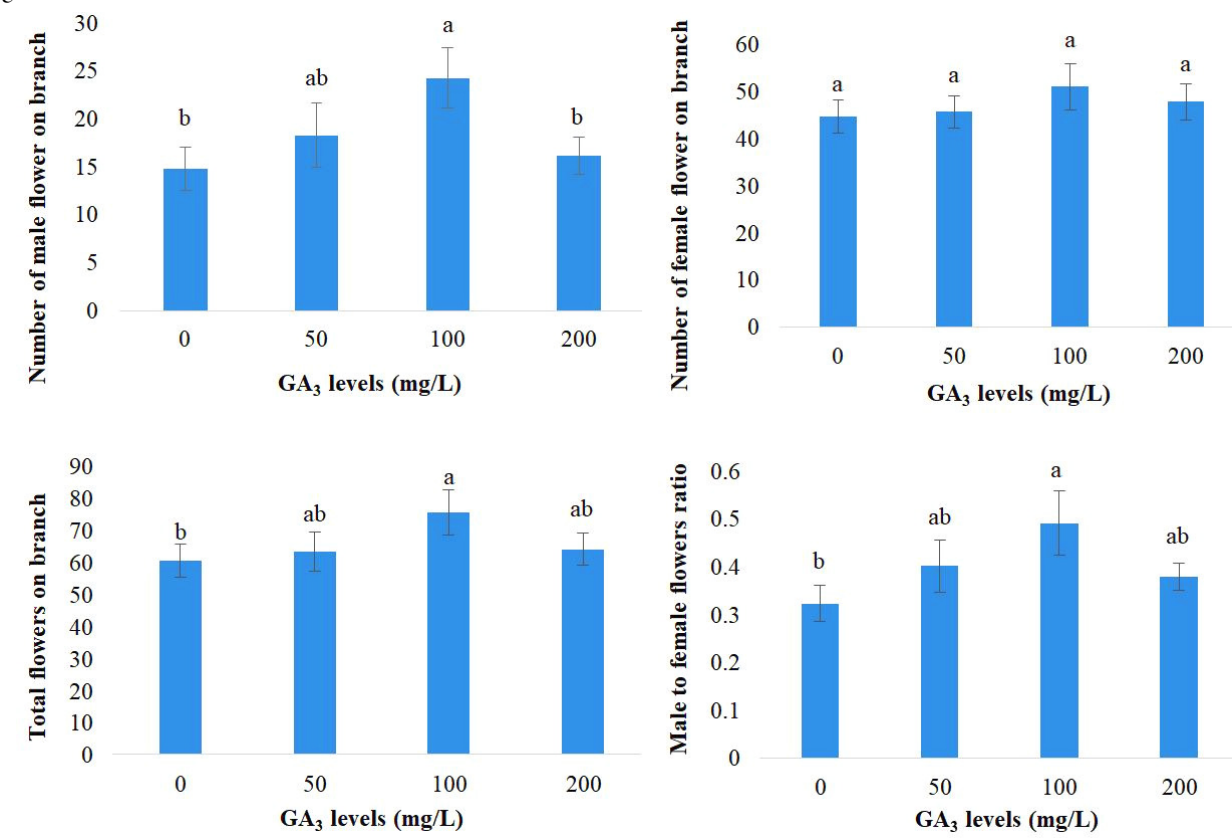

Fig. 2. Effects of $\mathrm{GA}_{3}$ on the number of male, female, and the ratio of male: female flowers and the total number of flowers in each branch of walnut trees during flower induction
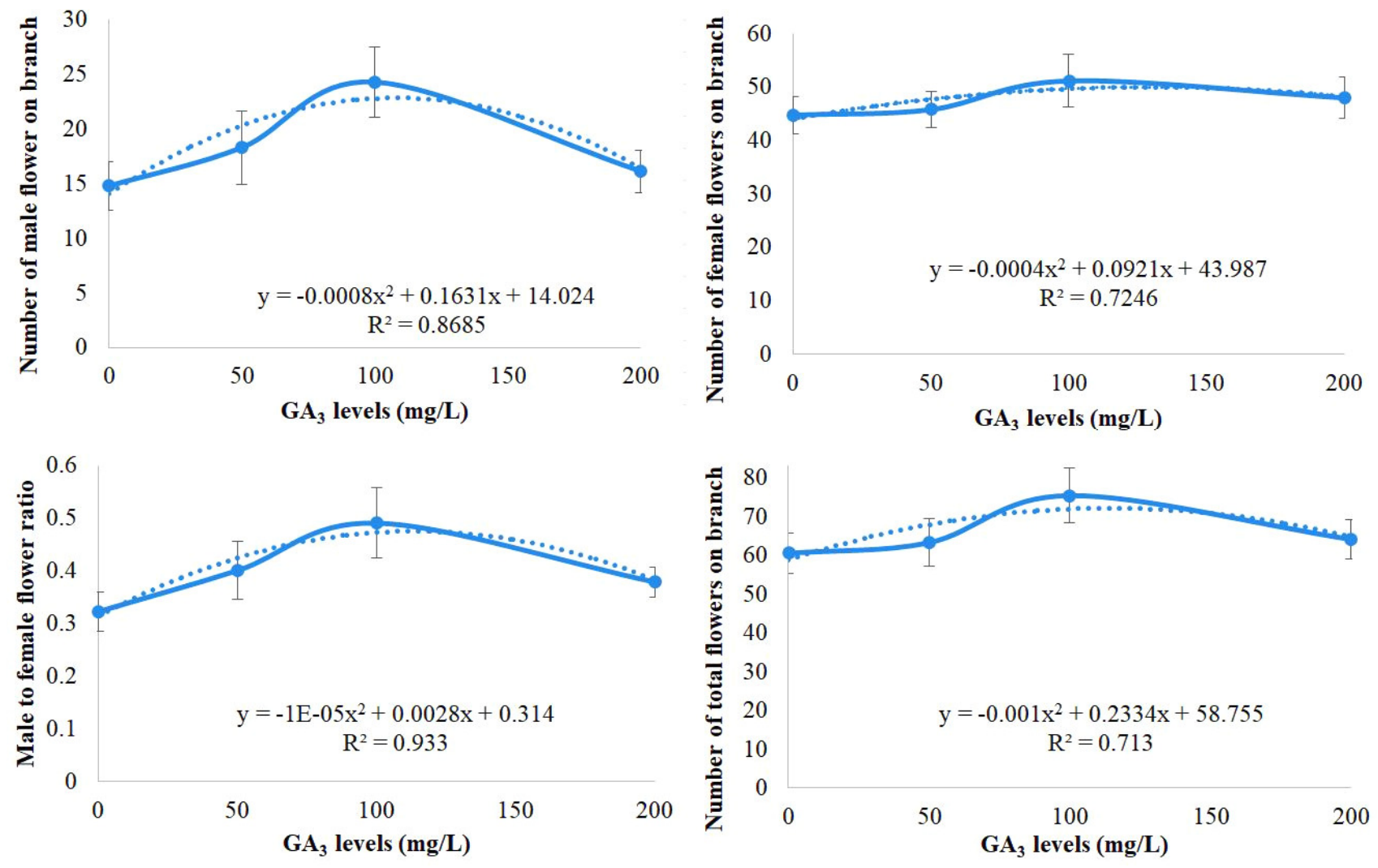

Fig. 3. Relationship between $\mathrm{GA}_{3}$ treatments and male, female, total and male to female ratio flowers on branches (each number is an average of 18 branches of six trees) 
705
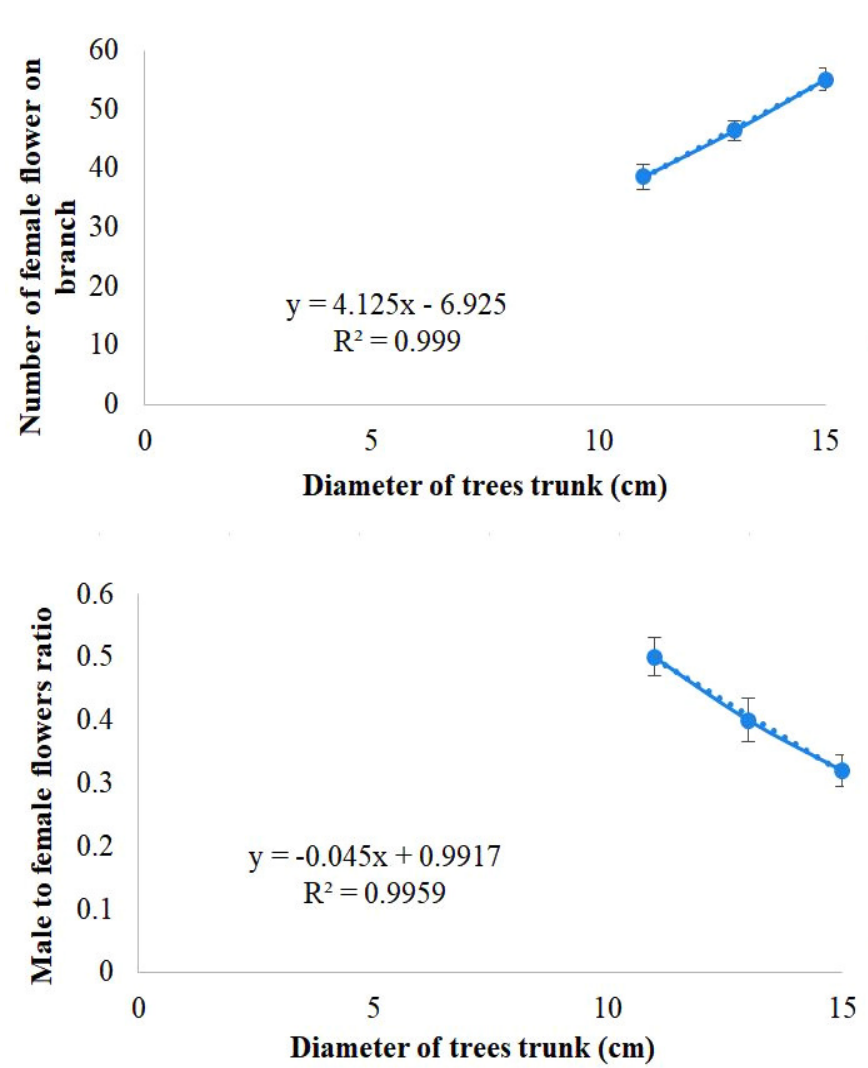
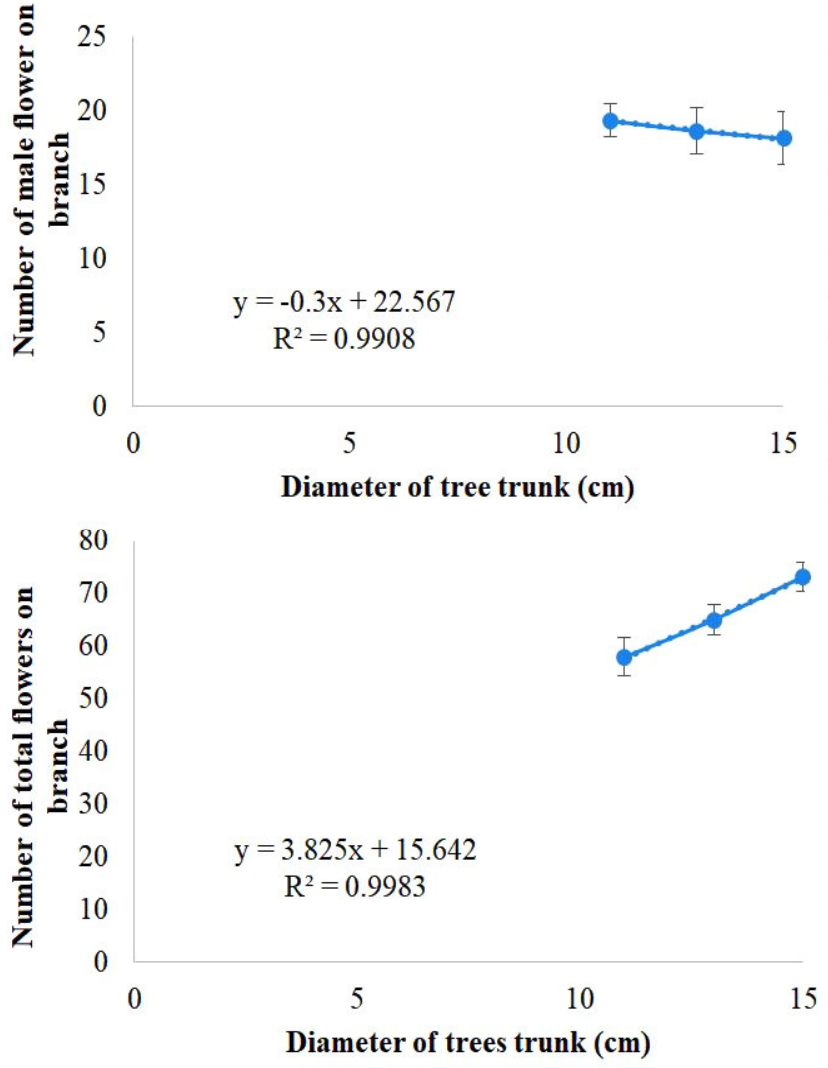

Fig. 4. Relationship between trunk diameter and male, female and total flowers, in addition to the male: female ratio of flowers in branches (Each number is an average of 24 branches of 8 trees)

\section{Conclusions}

In conclusion, the stages of flower development are divided into three stages. Different stages of development included induction, initiation, and differentiation of the pistillate flower bud, were observed respectively in late May and early June, September and March. As the $\mathrm{GA}_{3}$ was applied in the flowering induction stage, the number of male flowers increased. The need for pollinizer trees could be reduced by increasing the male flowers in walnut trees. More studies are needed to improve this hypothesis and understand the ability of $\mathrm{GA}_{3}$-treated pollinizer trees in commercial orchards.

\section{Acknowledgements}

We would like to thank Iran National Science Foundation (INSF), Center of Excellence of Walnut Improvement and Technology of Iran and University of Tehran for their financial supports. The authors also acknowledge Dr. Saadat Sarikhani Khorami and Mr. Mohsen Hamedpour Darabi for their English proofreading.

\section{References}

Akca Y, Ozgen M., Erturk U, ErcisliS (2012). The effects of AVG and GA3 treatments on pistillate (female) flower abortion in 'Sebin' walnut cultivar. ActaScientiarum Polonorum Hortorum Cultus 11:179-185.
Amiri R, Vahdati K, Mohsenipoor S, Mozaffari MR, Leslie C (2010). Correlations between some horticultural traits in walnut. HortScience 45:1690-1694.

Atefi J (1990). Preliminary research of Persian walnut and correlation between pair characters. Acta Horticulturae 284:97-104.

Bertin R, Kerwin M (1998). Floral sex ratios and gynomonoecy in Aster (Asteraceae). American Journal of Botany 85:235-235.

Bertin RI (2007). Sex allocation in Carex (Cyperaceae): effects of light, water, and nutrients. Botany 85:377-384.

Buide ML, del Valle JC, Castilla AR, Narbona E (2018). Sex expression variation in response to shade in gynodioecious-gynomonoecious species: Silene littorea decreases flower production and increases female flower proportion. Environmental and Experimental Botany 146:54 61.

Ćulafić L, Nešković M (1980). Effect of growth substances on flowering and sex expression in isolated apical buds of Spinacia oleracea. Physiologia Plantarum 48:588-591.

Forde HI, Griggs WH (1975). Pollination and blooming habits of walnuts. Univ CalifDiv Agr SciLflt 2753.

Forde HI, McGranahan GH (1996). Walnuts. In: Janick J, Moore JN (Eds). Fruit Breeding, Vol III: Nuts. John Wiley and Sons, Inc. New York, USA pp 241-273.

Galoch $\mathrm{E}$ (1978). The hormonal control of sex differentiation in dioecious plants of hemp (Cannabis sativa). The influence of plant growth regulators on sex expression in male and female plants. Acta Societatis 
Botanicorum Poloniae 47:153-162.

Galun E, Izhar S, Atsmon D (1965). Determination of relative auxin content in hermaphrodite and andromonoecious Cucumis sativus $\mathrm{L}$. Plant Physiology 40(2):321-326.

Gao Y, Liu H, Dong N, Pei D (2012). Temporal and spatial pattern of indole-3-acetic acid occurrence during walnut pistillate flower bud differentiation as revealed by immunohistochemistry. Journal of the American Society for Horticultural Science 137:283-289.

Ghani MA, Amjad M, Iqbal Q, Nawaz A, Ahmad T, Hafeez OBA, Abbas $M$ (2013).Efficacy of plant growth regulators on sex expression, earliness and yield components in bittergourd. Pakistan Journal of Life and Social Sciences 11(3):218-224.

Goldberg-Moeller R, Shalom L, Shlizerman L, Samuels S, Zur N, Ophir R, Blumwald E, Sadka A (2013). Effects of gibberellin treatment during flowering induction period on global gene expression and the transcription of flowering-control genes in Citrus buds. Plant Science 198:46-57.

Golzari M, Hassani D, Rahemi M, Vahdati K(2016).Xenia and Metaxenia in Persian Walnut (Juglans regia L.). Journal of Nuts 7:101-108.

Griffiths J, Murase K, Rieu I, Zentella R, Zhang ZL, Powers SJ, ... Sun TP (2006). Genetic characterization and functional analysis of the GID1 gibberellin receptors in Arabidopsis. The Plant Cell 18:3399-3414.

Hashizume H (1973). Studies on flower bud formation, flower sex differentiation and their control in conifers. Bull Tottori Univ For 7:1139.

Irish EE, Nelson T (1989). Sex determination in monoecious and dioecious plants. The Plant Cell 1(8):737-744.

Iwahori S, Lyons JM, Smith OE (1970). Sex expression in cucumber plants as affected by 2-chloroethylphosphonic acid, ethylene, and growth regulators. Plant Physiology 46:412-415.

Jack T (2004). Molecular and genetic mechanisms of floral control. The PlantCell 16:S1-S17.

Khryanin V (2002). Role of phytohormones in sex differentiation in plants. Russian Journal of Plant Physiology 49:545-551.

Krueger WH (2000). Pollination of English walnuts: practices and problems. HortTechnology 10:127-130.

Kumar N, Srivastava GC, Dixit K (2008). Flower bud opening and senescence in roses (Rosa bybrida L.). Plant Growth Regulation 55(2):81-99.

Li Y, Zhao Y, Yang K, Fang Y, Hou L (2011). Studies on floral organ development process of precocious walnut (Juglans regia) by anatomia. ActaHorticulturaeSinica 38:434440.

LiZ, WangS, Tao Q, Pan J, Si L, GongZ, Cai R (2012). A putative positive feedback regulation mechanism in CsACS2 expression suggests a modified model for sex determination in cucumber (Cucumissativus L.). Journal of Experimental Botany 63:4475-4484.

Makwana V,Shukla P, Robin P(2010). GAapplication induces alteration in sex ratio and cell death in Jatropha curca. Plant Growth Regulation 61:121-125.
Makwana V, Robin P (2013). Interaction between GA and ethrel in inducing female flowers in Jatropha curcas. International Journal of Biotechnology and Bioengineering Research 4:465-472.

Murai K (2013). Homeotic genes and the ABCDE model for floral organ formation in wheat. Plants 2:379-395.

Pimenta Lange MJ, Knop N, Lange T (2012). Stamen-derived bioactive gibberellin is essential for male flower development of Cucurbita maxima L. Journal of Experimental Botany 63:2681-2691.

Polito V, Aradhya M, Dang J, Grant J, Pinney K, Simon C, ... Woeste K (2003). Walnut pollination dynamics: pollen flow and pollen loads in walnut orchards. HortScience 38:741.

Qiguang Y, Lizhong R, Guohua D (1985). Effects of ethephon, GA3 and nutrient elements on sex expression of Chinese chestnut. Scientia Horticulturae 26:209-215.

Rijpkema AS, Vandenbussche M, Koes R, Heijmans K, Gerats T (2010). Variations on a theme: changes in the floral $\mathrm{ABCs}$ in angiosperms. Seminars in Cell \& Developmental Biology 21(1):100-107.

Sladký Z (1972). The role of endogenous growth regulators in the differentiation processes of walnut (Juglans regia L.). Biologia Plantarum 14:273-278.

Takahashi H, Jaffe M (1984). Further studies of auxin and ACC induced feminization in the cucumber plant using ethylene inhibitors. Phyton 44:81-86.

Trebitsh T, Rudich J, Riov J (1987). Auxin, biosynthesis of ethylene and sex expression in cucumber (Cucumis sativus). Plant Growth Regulation 5:105-113.

Ueguchi-Tanaka M, Matsuoka M (2010). The perception of gibberellins: clues from receptor structure. Current Opinion in Plant Biology 13:503-508.

Wilkie JD, Sedgley M, Olesen T (2008). Regulation of floral initiation in horticultural trees. Journal of Experimental Botany 59:3215-3228.

Young TE, Giesler-Lee J, Gallie DR (2004). Senescence-induced expression of cytokinin reverses pistil abortion during maize flower development. The Plant Journal 38:910-922.

Zhao P, Fan Jf, Zhang Sx, Huang Zl, Yang Ph, Ma Zh, Woeste KE (2011). Effects of gibberellin A 4/7, 6-benzylaminopurine and chlormequat chloride on the number of male and female strobili and immature cones in Chinese Pine (Pinus tabuliformis) with foliar sprays. Journal of forestry Research 22:353-359. 